ewangelizację, powiązanie wiary z tożsamością narodową oraz wpływ religii na kulturę ormiańską. P. Siniscalco - w przeciwieństwie do poprzedniego rozdziału - tylko pokrótce przedstawia późniejsze dzieje Kościoła ormiańskiego, a przecież należałoby więcej miejsca poświęcić historii Ormian na początku XX w. ze względu na ludobójstwo, które dotknęło ten naród z powodów religijnych.

Rozdział XIII przedstawia historię Kościoła gruzińskiego (s. 251-269). Autor w interesujący sposób pisze o Gruzji, łącząc jej historię z opowieściami mitologicznymi, i podkreśla, że chrześcijaństwo dla narodu gruzińskiego ma wymiar symboliczny.

Autorem rozdziału XIV, zatytułowanego Literatura patrystyczna $w$ Armenii $i$ Gruzji (s. 270-292), jest Michel van Esbroeck. Autor rozpoczyna swe rozważania od omówienia wspólnego dziedzictwa krajów kaukaskich, dalej ukazuje pojawiające się między nimi różnice, następnie zaś przechodzi do przedstawienia momentu całkowitego ich rozdzielenia. Po zaprezentowaniu powyższych treści opisuje niezależnie tworzącą się literaturę armeńską i gruzińską.

Reasumując należy powiedzieć, że książka Paolo Siniscalco Starożytne Kościoły Wschodnie. Historia i literatura jest bardzo wartościową pozycją przede wszystkim ze względu na podjętą tematykę oraz uzupełnienie pewnej luki, jaka istniała w literaturze dotyczącej historii Kościołów wschodnich. Największym atutem tej książki - moim zdaniem - jest bibliografia, która - również w języku polskim - została podana na końcu każdego rozdziału.

ks. Marcin Sobiech - Lublin, KUL

\title{
Robert WIŚNIEWSKI, Wróżbiarstwo chrześcijańskie w późnym antyku, czyli jak poznać przyszlość i nie utracić zbawienia, Warszawa 2013, Sub Lupa, ss. 265.
}

Nowa książka znanego historyka z Uniwersytetu Warszawskiego, Roberta Wiśniewskiego, jest przekrojową syntezą podsumowującą kilkuletnie badania prowadzone nad rekonstrukcją i oceną zjawiska wróżbiarstwa w środowisku chrześcijan późnego antyku. Autor prezentuje na podstawie zachowanych źródeł historyczno-literacko-teologicznych szeroką panoramę zagadnień związanych z nieakceptowanym oficjalnie przez chrześcijaństwo procederem wróżenia jako sposobem zdobywania wiedzy o przyszłości, który jednak występował, zwłaszcza wśród etnochrześcijan, usiłujących pogodzić go z nową religią.

R. Wiśniewski z dużą erudycją przedstawia w sposób oryginalny złożoność problemu i dokonuje nie podjętego dotąd w literaturze światowej na taką skalę usystematyzowania zagadnienia, korzystając krytycznie z rozproszonych po całej twórczości późnoantycznej tekstów źródłowych związanych z wróżbiarstwem uprawianym przez pogan i chrześcijan. Rzetelne analizy źródłowe skonfrontowane z najnowszą obcojęzyczną literaturą przedmiotu (na szczególną uwagę zasługują: wykorzystanie ostatnich badań dotyczących Sortes Sanctorum, zmieniających całkowicie sposób patrzenia na zjawisko określane tym terminem - ważna korekta 
thumaczenia kanonu 16. synodu w Vannes z najnowszego wydania Acta Synodalia 431-504 przygotowanego przez A. Barona i H. Pietrasa, Kraków 2011; oraz uwzględnienie badań archeologicznych umożliwiających udaną próbę systematyzacji geografii sanktuariów inkubacyjnych), doprowadziły Autora do uzasadnionych, twórczych wniosków. Głównym osiaggnięciem R. Wiśniewskiego jest wykazanie, że we wczesnym chrześcijaństwie, przynajmniej od połowy IV w., istniały w dużym stopniu (chociaż nie zawsze) wzorowane na wróżbiarstwie pogańskim, ale dostosowane do kontekstu religii chrześcijańskiej (lub niekiedy nawet w tym kontekście powstałe), praktyki dywinacyjne, rozpowszechnione wśród wiernych, a nawet duchownych, sądzących, że można pogodzić taką postawę z zasadami religii chrześcijańskiej, nieakceptowane natomiast zasadniczo (a przynajmniej niezalecane) przez hierarchię i prawo kościelne. Do występujących we wczesnym chrześcijaństwie metod dywinacyjnych, do tej pory często nieznanych lub niedostatecznie zbadanych, R. Wiśniewski zaliczył: wypytywanie proroków, bibliomancję, wróżenie z ksiąg i losów, zadawanie pytań opętanym oraz inkubację w sanktuariach. Każdemu z powyższych zjawisk poświęcił oddzielny rozdział swojej rozprawy.

Niewatpliwą zaletą opracowania jest szczegółowe ukazanie od strony historycznej, socjologicznej, religijnej i literackiej zjawiska, którego genezy, istoty i rozmiarów dotąd należycie nie poznano. R. Wiśniewski stawia słuszne pytania; stara się zachować obiektywizm; ,tkwi” w epoce, którą omawia; uwzględnia w interpretacji źródeł nie tylko szeroki kontekst historyczny, lecz także specyfikę gatunku literackiego każdego tekstu źródłowego, co jest specjalnością kierowanego przez prof. E. Wipszycką środowiska naukowego, z którego Autor się wywodzi.

Za najbardziej oryginalne, interesujące i przekonujące zarówno dla historyka starożytności, jak i dla patrologa, kulturoznawcy czy religioznawcy, uważam rozdziały poświęcone księgom, kościom i losom wróżbiarskim, wypytywaniu opętanych oraz inkubacji sakralnej. R. Wiśniewski przejrzyście ukazał zbieżności i różnice między wróżbiarstwem praktykowanym przez pogan i niektórych chrześcijan, uzasadniając słusznie pewne zależności wspólną atmosferą intelektualną, w której zjawiska te wyrastały (por. s. 72), zwracając też uwagę na specyficznie chrześcijański charakter takich metod wróżenia, jak na przykład wypytywanie opętanych.

R. Wiśniewski - mimo skąpych i rozbieżnych w swej treści przekazów źródłowych - podją także próbę oceny rozmiaru zjawiska wróżbiarstwa w chrześcijaństwie oraz ustalenia charakteru reakcji, z jaką spotykało się ono wśród hierarchii kościelnej. Odpowiedzi udzielone w tych dwóch kwestiach są interesujące i dają się obronić w świetle zachowanych źródeł, ale - między innymi właśnie z powodu skromności i niejednoznaczności bazy źródłowej, a więc z racji obiektywnych - nie są to odpowiedzi jedyne i ostateczne. Pozostaje także nadal otwarta kwestia, czy chrześcijanie stworzyli zupełnie nowy, odrębny rodzaj wróżbiarstwa, czy raczej wzorowali się na metodach pogańskich, które chcieli pogodzić z zasadami nowej religii. Autor monografii zdaje się sytuować swoją odpowiedź pośrodku, skłaniając się bardziej ku pierwszej możliwości i podkreślając oryginalność wróżbiarstwa chrześcijańskiego. Zastanawiam się jednak, czy nie należałoby raczej iść 
w kierunku drugiej możliwości, wróżbiarstwo bowiem, mimo pewnych analogii z prorokowaniem, było z natury chrześcijaństwu obce, na co starali się zwrócić uwagę teologowie i oficjalni przedstawiciele Kościoła. Milczenie źródeł w pewnych kwestiach lub umiarkowane przyzwalanie na niektóre praktyki dywinacyjne, jak to widać np. w cytowanej na s. 81 wypowiedzi Augustyna z Listu 55., nie zmienia - moim zdaniem - generalnie krytycznej oceny praktykowania wróżbiarstwa przez chrześcijan wśród znanych Ojców Kościoła i hierarchii.

Jak każde oryginalne ujęcie problemu recenzowana monografia prowokuje do dyskusji i nasuwa pewne wątpliwości. Po pierwsze, kwestia tytułu. Sformułowanie „wróżbiarstwo chrześcijańskie w późnym antyku” może sugerować, że istnieje jakiś szczególny, zinstytucjonalizowany rodzaj wróżbiarstwa w wydaniu chrześcijańskim, właściwy tej religii, a Autor bada to zjawisko w jednym z okresów historycznych. Tymczasem mamy do czynienia z chrześcijańską mutacją pewnego niechrześcijańskiego fenomenu, występującą wśród niektórych duchownych i wiernych, ale krytykowaną przez hierarchię jako niezgodną z duchem chrześcijańskiej religii. Dwuznaczny jest także podtytuł ,jak poznać przyszłość i nie utracić zbawienia", zaostrzający apetyt czytelnika oryginalnym sformułowaniem. $Z$ jednej strony słusznie zwraca on uwagę na istnienie wśród chrześcijan pierwszych wieków prób pogodzenia wyznawanej wiary z praktykami zaspokajającymi ludzką ciekawość spraw nieznanych bez naruszania poczucia czystego sumienia, ale na pierwszy rzut oka może też sugerować, że w religii chrześcijańskiej jest rzeczywiście dopuszczalne godzenie wróżbiarstwa z wiernością wyznawanej doktrynie, trzeba tylko wiedzieć, jak to robić; a to byłby już zbyt daleko posunięty wniosek, nawet jeżeli tak subiektywnie wydawało się wczesnochrześcijańskim uczestnikom i zwolennikom takich praktyk. Wolałbym więc raczej tytuł, jaki Autor nadał jednemu ze swoich wcześniejszych artykułów - „Chrześcijanie i wróżbiarstwo w późnej starożytności”, albo „Wróżbiarstwo w chrześcijaństwie późnego antyku. Istota i skala zjawiska".

Po drugie, nie przekonuje mnie stawianie obok siebie i traktowanie jako odmian wróżbiarstwa stosowanego przez chrześcijan tak różnych zjawisk, jak z jednej strony rzeczywiste praktyki wróżbiarskie w postaci ciagnięcia losów, wypytywania opętanych czy inkubacji, z drugiej - niezwykle złożony fenomen proroctwa, zdecydowanie wykraczający w rozumieniu judeochrześcijańskim poza czynności przewidywania przyszłości i udzielania rad w sprawach ziemskich lub duchowych, czy znane sytuacje zmiany drogi życiowej pod wpływem usłyszanych lub przeczytanych słów Pisma Świętego przez św. Antoniego i św. Augustyna, zaklasyfikowane jako przykład bibliomancji, czyli wróżenia z Pisma. Autor stara się wprawdzie niuansować powyższe zjawiska, ale czyni to czasem niezbyt wyraźnie lub zbyt późno, a konstrukcja pracy sprzyja wyliczaniu na jednym oddechu wszystkich wymienionych zachowań, powracającemu na kartach książki.

Po trzecie, autor próbuje ustalić i zrozumieć zarówno przyczyny postaw chrześcijan uciekających się do praktyk wróżbiarskich, jak i motywy działania krytyków takich zachowań na gruncie chrześcijańskim, jednak ocena tych ostatnich wydaje 
się niekiedy pozbawiona nieco wyczucia teologicznego i jest zabarwiona mniej lub bardziej świadomie - przynajmniej na poziomie niezbyt zręcznych sformułowań - ironią lub złośliwością. Sformułowania typu: „,pohukiwania kaznodziejów wypadały nieco blado” (s. 14), praktyki wróżbiarskie „niekiedy budziły pomruki niechęci pisarzy i kaznodziejów" (s. 240) to niepotrzebnie zabarwione emocjonalnie zwroty trącące nieco inwektywa, mogącą sugerować, że duchowni nie rozumieli potrzeb swoich współwyznawców i ograniczali ich wolność. Krytyka wróżbiarstwa miała z pewnością swoje głębsze teologiczne uzasadnienie, związane z istotą religii chrześcijańskiej, opartej na wierze w Opatrzność Bożą i wiążącej tę praktykę z działaniem złych duchów, czemu zresztą Autor wielokrotnie daje wyraz na kartach swojej książki, trudno więc określać ją równocześnie jako „pomruki niechęci” czy uzasadniać przede wszystkim obawą biskupów przed konkurencją dla swojej władzy (por. s. 58).

Po czwarte, pewne wątpliwości budzi odwołujące się do tekstu źródłowego sformułowanie Autora pojawiające się w podsumowaniu rozdziału VI zatytułowanego Wypytywanie opętanych: „W De divinatione daemonum (1-2) Augustyn opowiada, jak niektórzy chrześcijanie z Hippony - i to prawdziwie pobożni chrześcijanie, którzy zwykli spotykać się w domu biskupa - nie widzieli nic złego we wróżbiarstwie pogańskim, które - nawet jeśli pochodziło od złych duchów było jednak tolerowane przez Boga" (s. 178). Kontekst i znaczenie wypowiedzi Augustyna wydają mi się nieco inne niż prezentuje R. Wiśniewski. Biskup Hippony istotnie toczył dysputy z wiernymi na temat pogańskiego wróżbiarstwa, zaznaczył jednak na początku traktatu, że przedstawiane przez nich opinie, przeciwne do biskupich, miały na celu uzyskanie od Augustyna kontrargumentów, które można byłoby przedstawić poganom: „,magis contradicendo quaerere viderentur, quid paganis responderi oporteret". Wynika z tego, że chrześcijanie goszczący w domu biskupim widzieli we wróżbiarstwie pogańskim niebezpieczeństwo, na które chcieli znaleźć rozumną i skuteczną odpowiedź. Niezręcznością jest też mówienie o tolerowaniu wróżbiarstwa pochodzącego od złych duchów przez Boga. Użyta przez Augustyna forma łacińskiego czasownika ,permittere” oznacza, że Bóg daje przyzwolenie na takie działania lub je dopuszcza, to jednak nie to samo, co tolerancja zakładająca uznawanie czy nawet akceptację, a przynajmniej wyrozumiałość wobec jakiegoś zjawiska.

R. Wiśniewski wykazuje znakomitą orientację w literaturze antycznej i wczesnochrześcijańskiej, jest erudytą o dużej wiedzy historycznej, którą operuje swobodnie w celu dokonania wielu pogłębionych porównawczych analiz. $Z$ drobnych usterek faktograficznych chciałbym tylko zwrócić uwagę na dwie sprawy:

1) egzegeza alegoryczna tekstów biblijnych święciła triumfy już w wieku III (kiedy to w Kościele wschodnim osiagnęła swoje apogeum w twórczości Orygenesa), a nie dopiero w wieku IV (jak pisze Autor na s. 74, powołując się zresztą w przypisie 2 . na Orygenesa), gdy powstała wobec niej opozycja w środowisku antiocheńskim; 2) na s. 227 chodzi Autorowi zapewne o cytowane wcześniej teksty Cyryla Aleksandryjskiego, a nie Cyryla Jerozolimskiego. 
Krótkiego komentarza wymaga kwestia wykorzystania i zapisu pozycji bibliograficznych. Książka R. Wiśniewskiego jest dziełem wybitnie źródłowym, chociaż - jak zauważa Autor we wstępnych uwagach metodologicznych - baza źródłowa jest z jednej strony bardzo rozproszona, z drugiej - niesłychanie skapa (por. s. 2). Tym większe słowa uznania należą się Autorowi za żmudne wydobywanie nielicznych wzmianek o wróżbiarstwie z różnych dzieł późnego antyku. Teksty źródłowe są obficie cytowane w pracy i odnotowywane w przypisach, a we wstępie znajduje się bardzo pożyteczna, sumaryczna charakterystyka bazy źródłowej. Szkoda jednak, że Autor zrezygnował z tradycyjnego zestawienia najważniejszych źródeł w specjalnym wykazie bibliograficznym wraz z podaniem wydań krytycznych, z których korzystał. Jeśli chodzi o to, co zgodnie z zapisem Autora wyczerpuje znamiona bibliografii, czyli o współczesną literaturę przedmiotu, trzeba przyznać, że R. Wiśniewski orientuje się świetnie w najnowszym światowym stanie badań (np. znajomość aktualnych poglądów na temat Sortes Sanctorum czy Ewangelii Marii), uwzględnia publikacje ściśle związane z tematem $\mathrm{i}-\mathrm{w}$ jego przekonaniu - najwartościowsze, unikając zbędnej abundancji uniemożliwiającej odróżnienie pozycji ważkich od przeciętnych. Zabrakło jednak wzmianki o przynajmniej jednym polskim opracowaniu ściśle związanym z tematyką książki. Pozycja Pawła Wygralaka pt. Stanowisko Kościoła wobec idolatrii i magii na terenie Galii i Hiszpanii w późnej starożytności chrześcijańskiej (VI-VII w.) (Poznań 2011), zawierająca obszerny rozdział poświęcony wróżbom i magii, powinna zostać po pierwsze zauważona, po drugie - krytycznie oceniona, tym bardziej, że Wygralak zna i cytuje publikacje Wiśniewskiego. P. Wygralak wykorzystał w swoim opracowaniu interesujące opracowania z kręgu hiszpańskojęzycznego, których nie cytuje R. Wiśniewski, a które z pewnością ubogaciłyby obraz wróżbiarstwa we wczesnym chrześcijaństwie: R. Sanz Serrano, Adivinación y sociedad en la Hispania tardoromana y visigoda, „Anejos de Gerión” 2 (1989) 365-390; A. De Mier Vélez, Supersticiones y horóscopos entre cristianos visigodos y francos, „Religión y Cultura” 41 (1995) 811-839.

Na pochwałę zasługuje redakcja książki od strony literackiej. Jej lektura jest przyjemna ze względu na precyzyjny, a przy tym piękny styl i język wypowiedzi, co - niestety - w ostatnim czasie nie jest oczywistością nawet w przypadku prac z zakresu szeroko pojętej humanistyki.

Monografia R. Wiśniewskiego stanowi wnikliwe opracowanie porządkujące i wyjaśniające twórczo wiele kwestii związanych ze zjawiskiem wróżbiarstwa w późnym antyku i wczesnym chrześcijaństwie, podejmowanych w literaturze zachodniej w formie przyczynków lub tylko sygnalizowanych w przekrojowych opracowaniach. Można ją uznać za współczesne uzupełnienie klasycznej pozycji A. Bouché-Leclercqa - Histoire de la divination dans l'Antiquité (Paris 18791882) oraz nowszych książek: S.I. Johnston - Ancient Greek Divination (Oxford 2008) i D. Aune'a - Prophecy in Early Christianity and Ancient Mediterranean World (Grand Rapids 1983). 